\title{
Inhibition Effect of Benzohydrazide Derivatives on Corrosion Behaviour of Mild Steel in 1 M HCl
}

\author{
P. Mohan, R. Usha, G. Paruthimal Kalaignan, and V. S. Muralidharan \\ Advanced Materials Research Laboratory, Department of Industrial Chemistry, Alagappa University, Karaikudi 630 003, India \\ Correspondence should be addressed to G. Paruthimal Kalaignan; pkalaignan@yahoo.com
}

Received 23 January 2012; Revised 4 June 2012; Accepted 6 June 2012

Academic Editor: Ali Nokhodchi

Copyright (C) 2013 P. Mohan et al. This is an open access article distributed under the Creative Commons Attribution License, which permits unrestricted use, distribution, and reproduction in any medium, provided the original work is properly cited.

\begin{abstract}
The inhibiting effect of N-benzylidenebenzohydrazide (BBH) and $\mathrm{N}^{\prime}$-(3-phenylallylidene) benzohydrazide (PABH) on the corrosion inhibition of mild steel in $1 \mathrm{M} \mathrm{HCl}$ solutions were determined by weight loss and electrochemical methods. These inhibitors were adsorbed on the surface according to Langmuir adsorption isotherm. Both $\mathrm{BBH}$ and $\mathrm{PABH}$ have offered inhibition efficiencies upto $97 \%$. The free energy of activation for the corrosion process has suggested the participation of these molecules in the corrosion process. The adsorbed inhibitor complex has offered barrier protection and prevented the corrosion. The dissolution of iron was also retarded thereby they inhibited corrosion. The surface morphology analysis confirmed the presence of a film on the surface.
\end{abstract}

\section{Introduction}

Acidizing inhibitors are added to reduce base metal corrosion [1]. Most of the acid corrosion inhibitors are organic compounds such as those containing $\mathrm{N}, \mathrm{S}, \mathrm{O}$, and aromatic rings. They adsorb on the metal surface. In most of the studies, the formation of donor-acceptor surface complexes between free or $\pi$ electrons of an inhibitor and vacant d-orbital of metal atoms was proposed [2-4]. The adsorption of organic inhibitors at the metal/solution interface takes place through the replacement of water molecules by organic molecules according to the following process [5]:

$$
\mathrm{Org}_{(\mathrm{sol})}+x \mathrm{H}_{2} \mathrm{O}_{(\mathrm{ads})} \longrightarrow \mathrm{Org}_{(\mathrm{ads})}+x \mathrm{H}_{2} \mathrm{O}
$$

where $\operatorname{Org}_{(\text {(sol) }}$ and $\operatorname{Org}_{(\mathrm{ads})}$ are organic molecules in the solution and adsorbed on the steel surface, respectively, $x$ is the number of water molecules replaced by the organic molecules. The Schiff base of cinnamaldehyde and $\mathrm{p}$ anisidine gave $65 \%$ inhibition [6] in acid solutions at $55^{\circ} \mathrm{C}$. Other Schiff base compounds have offered better inhibition than their amines and aldehydes [7-12]. Benzimidazole molecule and their derivatives have been exploited as corrosion inhibitors, as the molecule has two anchoring sites available for surface bonding which are the nitrogen atom with its lonely $\mathrm{sp}^{2}$ electron pair and the aromatic rings [1316]. Triazoles, substituted triazoles adsorb on steel surfaces and inhibit corrosion [17-19]. Substituted thioamides were found to offer inhibition by forming Fe-inhibitor complex on the surface [20]. The search for environmental friendly corrosion inhibitor has resulted in the development of triazole derivatives [21]. The inhibition action of hydrazone derivatives was performed via adsorption on the surface obeying Frumkin adsorption isotherm [22].

In this paper, inhibitive action of $\mathrm{BBH}$ and $\mathrm{PABH}$ compounds on mild steel corrosion in $1 \mathrm{M} \mathrm{HCl}$ was studied using weight loss study and electrochemical techniques. The effect of temperature on the corrosion behaviour of mild steel in $1 \mathrm{M} \mathrm{HCl}$ with optimum concentration of inhibitor was studied in the temperature ranging $303-383 \mathrm{~K}$.

\section{Experimental Details}

Mild steel coupons composed of $0.760 \%$ C, $0.019 \% \mathrm{Mn}$, $0.050 \% \mathrm{Cr}, 0.026 \% \mathrm{Si}, 0.012 \% \mathrm{P}, 0.023 \% \mathrm{Al}, 0.135 \% \mathrm{Cu}$, $0.050 \% \mathrm{Ni}$, and remainder being iron were used. Mild steel, strips coated with lacquer with an exposed area of $1 \mathrm{~cm}^{2}$ were used. $\mathrm{BBH}$ and $\mathrm{PABH}$ inhibitors were newly synthesized by condensation of benzohydrazide with appropriate aldehydes. These compounds were characterized through their spectral 
TABLE 1: Names and structural formulae of compounds benzohydrazide derivatives.

Compound

TABLE 2: Corrosion parameters derived from weight loss measurements in $1 \mathrm{M} \mathrm{HCl}$ containing $\mathrm{N}^{\prime}$-benzylidenebenzohydrazide $(\mathrm{BBH})$ at $303 \mathrm{~K}$.

\begin{tabular}{lccc}
\hline$C(\mathrm{mM})$ & $\begin{array}{c}\text { Corrosion rate } \\
(\mathrm{mmpy})\end{array}$ & $\begin{array}{c}\text { Surface } \\
\text { coverage } \\
(\theta)\end{array}$ & $\begin{array}{c}\text { Inhibition } \\
\text { efficiency } \\
(\%)\end{array}$ \\
\hline 0.00 & 332.28 & - & - \\
0.46 & 37.56 & 0.89 & 88.69 \\
0.89 & 21.05 & 0.93 & 93.66 \\
1.34 & 16.09 & 0.95 & 95.15 \\
1.78 & 11.05 & 0.96 & 96.52 \\
2.23 & 8.87 & 0.97 & 97.32 \\
\hline
\end{tabular}

TABLE 3: Corrosion parameters derived from weight loss measurements in $1 \mathrm{M} \mathrm{HCl}$ containing $\mathrm{PABH}$ at $303 \mathrm{~K}$.

\begin{tabular}{lccc}
\hline$C(\mathrm{mM})$ & $\begin{array}{c}\text { Corrosion rate } \\
(\mathrm{mmpy})\end{array}$ & $\begin{array}{c}\text { Surface coverage } \\
(\theta)\end{array}$ & $\begin{array}{c}\text { IE } \\
(\%)\end{array}$ \\
\hline 0.00 & 332.28 & - & - \\
0.40 & 41.27 & 0.88 & 87.57 \\
0.80 & 32.76 & 0.90 & 90.24 \\
1.20 & 26.41 & 0.92 & 92.04 \\
1.60 & 18.16 & 0.94 & 94.53 \\
2.00 & 7.84 & 0.97 & 97.43 \\
\hline
\end{tabular}

TABLE 4: Effect of $2.23 \mathrm{mM}$ of $\mathrm{BBH}$ and $2.00 \mathrm{mM}$ of PABH on corrosion in $1 \mathrm{M} \mathrm{HCl}$ at different temperatures (weight loss method) -1 hour immersion.

\begin{tabular}{lccccc}
\hline \multirow{2}{*}{ Temp. (K) } & \multicolumn{3}{c}{ Corrosion rate (mmpy) } & \multicolumn{2}{c}{ IE (\%) } \\
& Blank & BBH & PABH & BBH & PABH \\
\hline 303 & 644.55 & 79.68 & 71.88 & 87.6 & 88.84 \\
323 & 768.38 & 188.69 & 184.69 & 75.45 & 76.03 \\
343 & 935.25 & 364.13 & 349.39 & 61.06 & 62.64 \\
363 & 1222.85 & 648.36 & 581.21 & 49.43 & 52.47 \\
383 & 1551.69 & 1008.44 & 935.51 & 34.97 & 38.54 \\
\hline
\end{tabular}

data. Their purity was confirmed by TLC. Table 1 presents the structural formulae of these compounds.

A conventional three-electrode cell containing platinum foil as counter electrode, saturated calomel electrode (SCE) provided with the Luggin capillary as reference electrode, and a mild steel specimen as working electrode were used.
Experiments were performed using EG \& G Electrochemical analyzer (model 6310) at $303 \mathrm{~K}$. Electrochemical impedance spectroscopy measurements were carried out between $100 \mathrm{kHz}-10 \mathrm{mHz}$ frequency range at steady open circuit potential with an amplitude of $10 \mathrm{mV}$. The protective film formed on the surface of the mild steel specimens was investigated by SEM.

\section{Results and Discussion}

3.1. Weight Loss Studies. Corrosion inhibition efficiencies (\%) offered by $\mathrm{N}^{\prime}$-benzylidenebenzohydrazide at $303 \mathrm{~K}$ after 3 hours immersion are given in Table 2 . IE \% was increased with increase of concentration $\mathrm{BBH}$. Table 3 presents the $\%$ IE efficiency offered by $\mathrm{N}^{\prime}$-(3-phenylallylidene) benzohydrazide. $2.00 \mathrm{mM}$ concentration of $\mathrm{PABH}$ has offered $97.43 \%$ IE. Corrosion inhibition studies were carried out for different temperatures after immersing the steel specimens for an hour. At different temperature studies, $\mathrm{BBH}$ and $\mathrm{PABH}$ have offered good corrosion inhibition. However, the inhibition efficiencies were decreased with rise in temperatures (Table 4). High inhibition efficiency of these compounds were attributed to the presence of extensively delocalized $\pi$ electrons of the phenyl rings, planarity and the presence of lone pair of electrons on $\mathrm{N}$ atoms, which favored greater adsorption of $\mathrm{BBH}$ and $\mathrm{PABH}$ on the metal surface at $303 \mathrm{~K}$ [23].

3.2. Electrochemical Methods. Polarization experiments were studied in $1 \mathrm{M} \mathrm{HCl}$ solution containing different concentrations of $\mathrm{BBH}$ and $\mathrm{PABH}$ (Figures 1 and 2). The linear segments of the anodic and cathodic polarization curves were extrapolated to the corrosion potentials to calculate corrosion currents. The Tafel slopes were determined from Tafel region of current-potential curves. The corrosion current densities were calculated by extrapolation of linear parts of these curves to corresponding corrosion potentials. The electrochemical parameters that is, corrosion potential $\left(E_{\text {corr }}\right)$ anodic $\left(b_{a}\right)$ and cathodic $\left(b_{c}\right)$ Tafel slopes, corrosion current densities $\left(i_{\text {corr }}\right)$ and inhibition efficiencies (IE\%) determined from polarization curves are presented in Tables 5 and 6 . In both the solutions, corrosion potentials became nobler. It can be seen from Tables 5 and 6 that, although $E_{\text {corr }}$ and $b_{c}$ values are nearly remained the same, $b_{c}$ values of $\mathrm{PABH}$ shifted to lower values as inhibitor concentration 
TABLE 5: Electrochemical parameters derived from potentiodynamic polarization curves for mild steel in $1 \mathrm{M} \mathrm{HCl}$ containing $\mathrm{BBH}$ at $303 \mathrm{~K}$.

\begin{tabular}{lccccc}
\hline$C(\mathrm{mM})$ & $\begin{array}{c}E_{\text {corr }} \\
(\mathrm{mV} \text { versus }(\mathrm{SCE}))\end{array}$ & $\begin{array}{c}b_{a} \\
\left(\mathrm{mV} \mathrm{dec}^{-1}\right)\end{array}$ & $\begin{array}{c}b_{c} \\
\left(\mathrm{mV} \mathrm{dec}^{-1}\right)\end{array}$ & $\begin{array}{c}I_{\text {corr }} \\
\left(\mathrm{mA} / \mathrm{cm}^{2}\right)\end{array}$ & $\begin{array}{c}1.597 \\
\mathrm{IE}(\%)\end{array}$ \\
\hline 0.00 & -468 & 111 & 55 & 0.212 \\
0.45 & -498 & 107 & 72 & 0.141 & 86.17 \\
0.89 & -494 & 143 & 65 & 0.966 \\
1.34 & -504 & 89 & 82 & 0.899 \\
1.78 & -478 & 125 & 81 & 91.16 \\
2.23 & -477 & 128 & 64 & 0.688 & 93.95 \\
\hline
\end{tabular}

TABLE 6: Electrochemical parameters derived from potentiodynamic polarization curves for mild steel in $1 \mathrm{M} \mathrm{HCl} \mathrm{containing} \mathrm{PABH}$ at $303 \mathrm{~K}$.

\begin{tabular}{lccccc}
\hline$C(\mathrm{mM})$ & $\begin{array}{c}E_{\text {corr }} \\
(\mathrm{mV} \text { versus }(\mathrm{SCE}))\end{array}$ & $\begin{array}{c}b_{a} \\
\left(\mathrm{mV} \mathrm{dec}^{-1}\right)\end{array}$ & $\begin{array}{c}b_{c} \\
\left(\mathrm{mV} \mathrm{dec}^{-1}\right)\end{array}$ & $\begin{array}{c}I_{\text {corr }} \\
\left(\mathrm{mA} / \mathrm{cm}^{2}\right)\end{array}$ & 1.597 \\
\hline 0.00 & -468 & 111 & 55 & 0.296 \\
0.40 & -484 & 108 & 86 & 0.159 & 87.10 \\
0.80 & -482 & 120 & 93 & 0.150 & 89.24 \\
1.20 & -474 & 75 & 70 & 0.136 \\
1.60 & -450 & 70 & 95 & 90.38 \\
2.00 & -486 & 66 & 64 & 91.108 & 93.23 \\
\hline
\end{tabular}

TABLE 7: Electrochemical parameters derived from Nyquist diagrams for mild steel in $1 \mathrm{M} \mathrm{HCl}$ containing $\mathrm{BBH}$ at $303 \mathrm{~K}$.

\begin{tabular}{lccc}
\hline$C(\mathrm{mM})$ & $R_{\mathrm{ct}}\left(\Omega \mathrm{cm}^{2}\right)$ & $C_{\mathrm{dl}}\left(\mu \mathrm{F} / \mathrm{cm}^{2}\right)$ & $\mathrm{IE} \%)$ \\
\hline 0.00 & 20 & 492.00 & - \\
0.45 & 167 & 83.43 & 88 \\
0.89 & 311 & 68.51 & 93 \\
1.34 & 708 & 41.02 & 97 \\
1.78 & 1102 & 24.16 & 98 \\
2.23 & 1570 & 15.58 & 98 \\
\hline
\end{tabular}

TABLE 8: Electrochemical parameters derived from Nyquist diagrams for mild steel in $1 \mathrm{M} \mathrm{HCl}$ containing $\mathrm{PABH}$ at $303 \mathrm{~K}$.

\begin{tabular}{lccc}
\hline$C(\mathrm{mM})$ & $R_{\mathrm{ct}}\left(\Omega \mathrm{cm}^{2}\right)$ & $C_{\mathrm{dl}}\left(\mu \mathrm{F} / \mathrm{cm}^{2}\right)$ & IE $(\%)$ \\
\hline 0.00 & 20 & 492.00 & - \\
0.40 & 135 & 92.12 & 85 \\
0.80 & 191 & 74.57 & 89 \\
1.20 & 341 & 47.64 & 94 \\
1.60 & 733 & 35.02 & 97 \\
2.00 & 1108 & 21.08 & 98 \\
\hline
\end{tabular}

is increased. Corrosion current densities decreased with increase between increase inhibitor concentrations. Corrosion inhibition increased upto $95 \%$ for $\mathrm{BBH}$ and $93 \%$ for $\mathrm{PABH}$, respectively.

The Nyquist plots of mild steel obtained in $1 \mathrm{M} \mathrm{HCl} \mathrm{solu-}$ tion in the absence and presence of various concentrations of inhibitors and the data obtained are given in Figures 3 and 4. The related electrochemical parameters were calculated and are shown in Tables 7 and 8 at open circuit potential in presence and absence of different concentrations of $\mathrm{BBH}$ and $\mathrm{PABH}$ (Figures 3 and 4). Single distorted semicircles were observed in Nyquist plots suggesting a simple $R-C$ circuit. Increase the $\mathrm{BBH}$ and $\mathrm{PABH}$ concentrations decreased the double layer capacitance values (Tables 7 and 8). In inhibitor free solution the observed capacitance values $492 \mu \mathrm{F} \mathrm{cm}{ }^{-2}$ was due to the pseudocapacitance. This capacitance would have been due to the adsorption of corrosion products on the surface of steel. Higher charge transfer resistances indicate the decreases in corrosion current densities. The percentage of inhibition efficiencies increased with $\mathrm{BBH}$ and $\mathrm{PABH}$ concentrations. The values of double layer capacitance $\left(C_{\mathrm{dl}}\right)$ were decreased and the charge transfer resistance $\left(R_{\mathrm{ct}}\right)$ increased with inhibitor concentration. The appearance of depressed semicircle is due to high frequency dispersion [24] or due to surface heterogeneity or corrosion products covering the surface at random sites $[25,26]$. Both the electrochemical methods offered nearly same \% IE values for both inhibitors.

3.3. Surface Examination. The surface morphologies of iron after $3 \mathrm{~h}$ immersion in the solution containing inhibitor and inhibitor free conditions are shown. A polished mild steel surface (Figure 5(a)) became covered with corrosion products at selected sites (Figure 5(b)) in $1 \mathrm{M} \mathrm{HCl}$ solutions. Smooth surfaces were seen for mild steel specimens after immersion in $1 \mathrm{M} \mathrm{HCl}$ solutions containing inhibitors as shown in Figures 5(c) and 5(d).

3.4. Adsorption Isotherms. $\mathrm{BBH}$ and $\mathrm{PABH}$ molecules have adsorbed on the mild steel surface due to Vander Waals forces. The presence of extensively delocalized $\pi$ electrons of the phenyl rings and presence of lone pair of electrons on $\mathrm{N}$ atoms have favoured greater adsorption [26]. Adsorptions of these organic molecules have displaced the water molecules from the metal surface. The interaction between the organic 


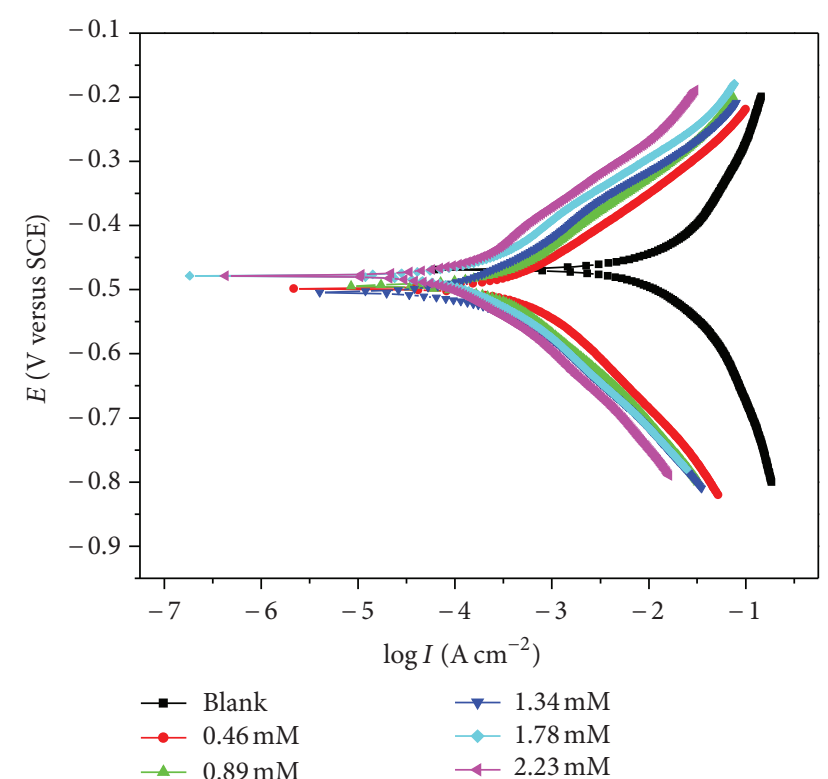

FIgURE 1: Polarization curves for mild steel in $1 \mathrm{M} \mathrm{HCl}$ with different concentrations of $\mathrm{BBH}$.

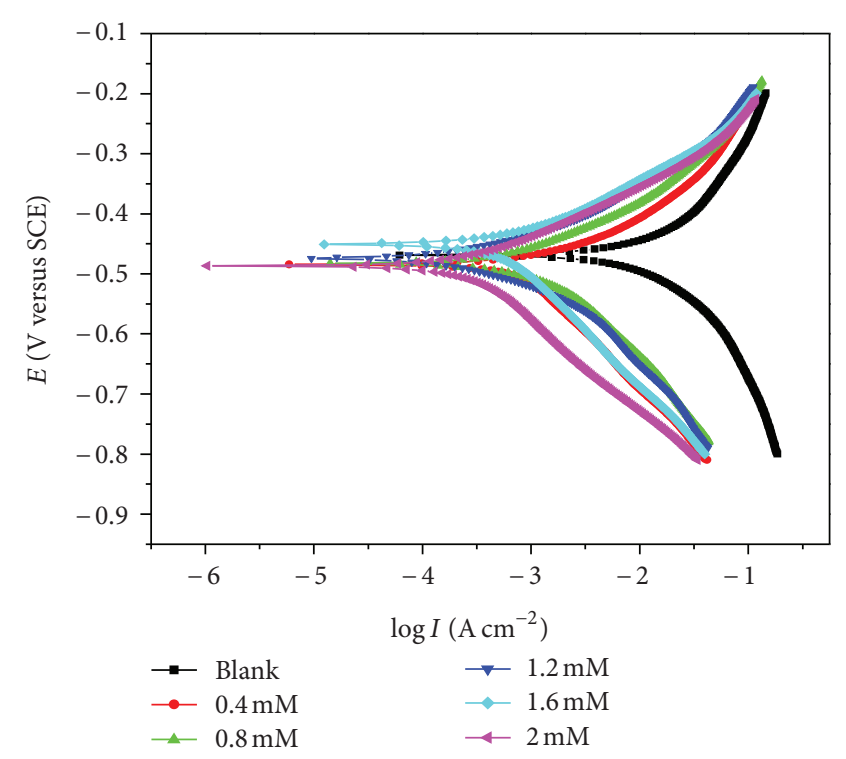

FIgURE 2: Polarization curves for mild steel in $1 \mathrm{M} \mathrm{HCl}$ solution without and with $\mathrm{PABH}$.

molecules and the metal surfaces are obtained from various isotherms. Percentage inhibition efficiency was obtained from weight loss measurements as surface coverage $(\theta)$. According to the Langmuir adsorption isotherm, the surface coverage $(\theta)$ is related to inhibitor concentration $(C)$ by the following equation

$$
\frac{C}{\theta}=\frac{1}{K_{\mathrm{ads}}}=C,
$$

where $K_{\mathrm{ads}}$ is the equilibrium constant of the inhibitor adsorption process. Figure 6 presents the plot of $C / \theta$ versus $C$ for both the inhibitors. A straight line fit with a correlation

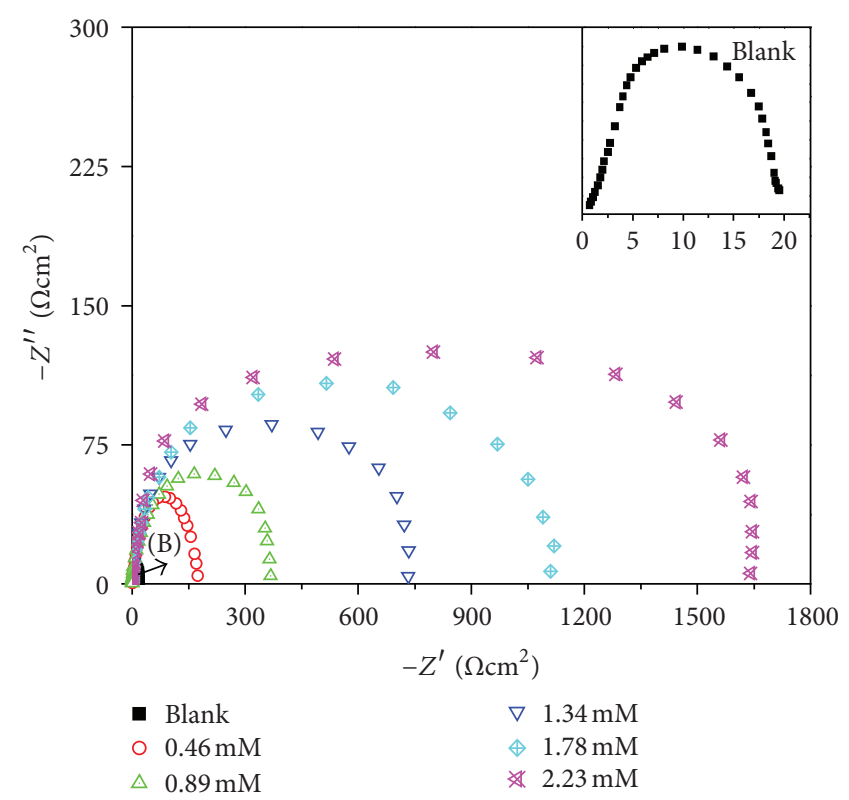

FIGURE 3: Nyquist diagrams for mild steel in $1 \mathrm{M} \mathrm{HCl}$ with different concentration of $\mathrm{BBH}$.

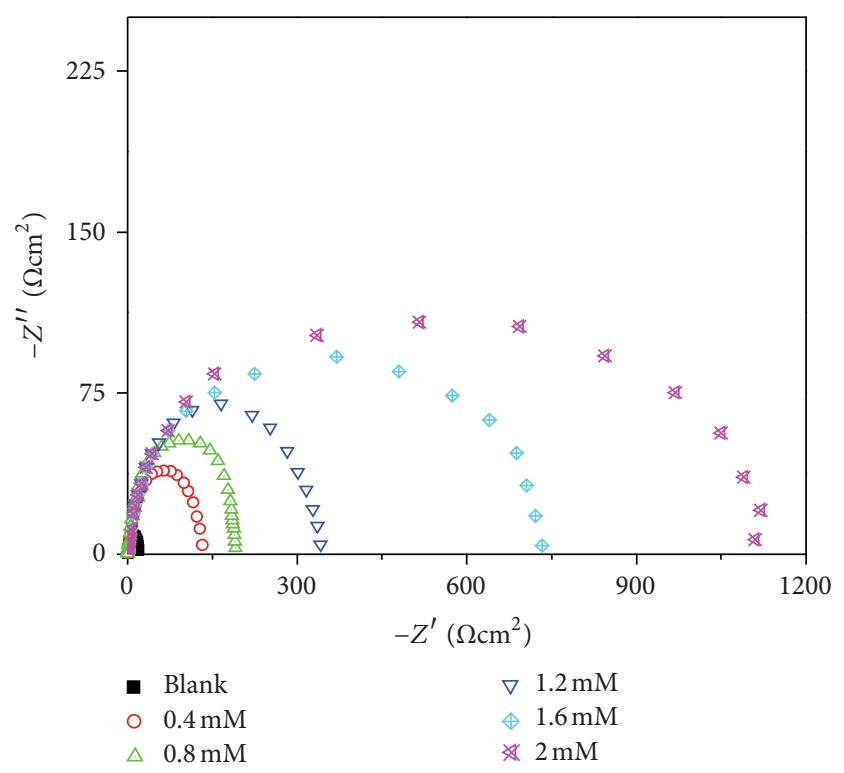

FIGURE 4: Nyquist diagrams for mild steel in $1 \mathrm{M} \mathrm{HCl}$ with different concentration of PABH.

of 0.999 suggests the adsorption obeys Langmuir adsorption isotherm. Using $K_{\text {ads }}$ value, $\left(\Delta G_{\text {ads }}^{0}\right)$ was calculated:

$$
\Delta G_{\mathrm{ads}}^{0}=-R T l \ln \left(55.5 K_{\mathrm{ads}}\right),
$$

where $R$ is the gas constant and $T$ is the absolute temperature. The value of 55.5 is the concentration of water in solution. The values of $\Delta G_{\text {ads }}^{0}$ were -32.12 and $-34.56 \mathrm{~kJ} / \mathrm{mol}$ for $\mathrm{BBH}$ and $\mathrm{PABH}$, respectively. The negative value of $\Delta G_{\mathrm{ads}}^{0}$ suggests the chemisorptions of these inhibitors. This is due to electrostatic interactions between the charged molecules and the metal. The $\Delta G_{\text {ads }}^{0}$ values more than $-40 \mathrm{~kJ} /$ mole involve 

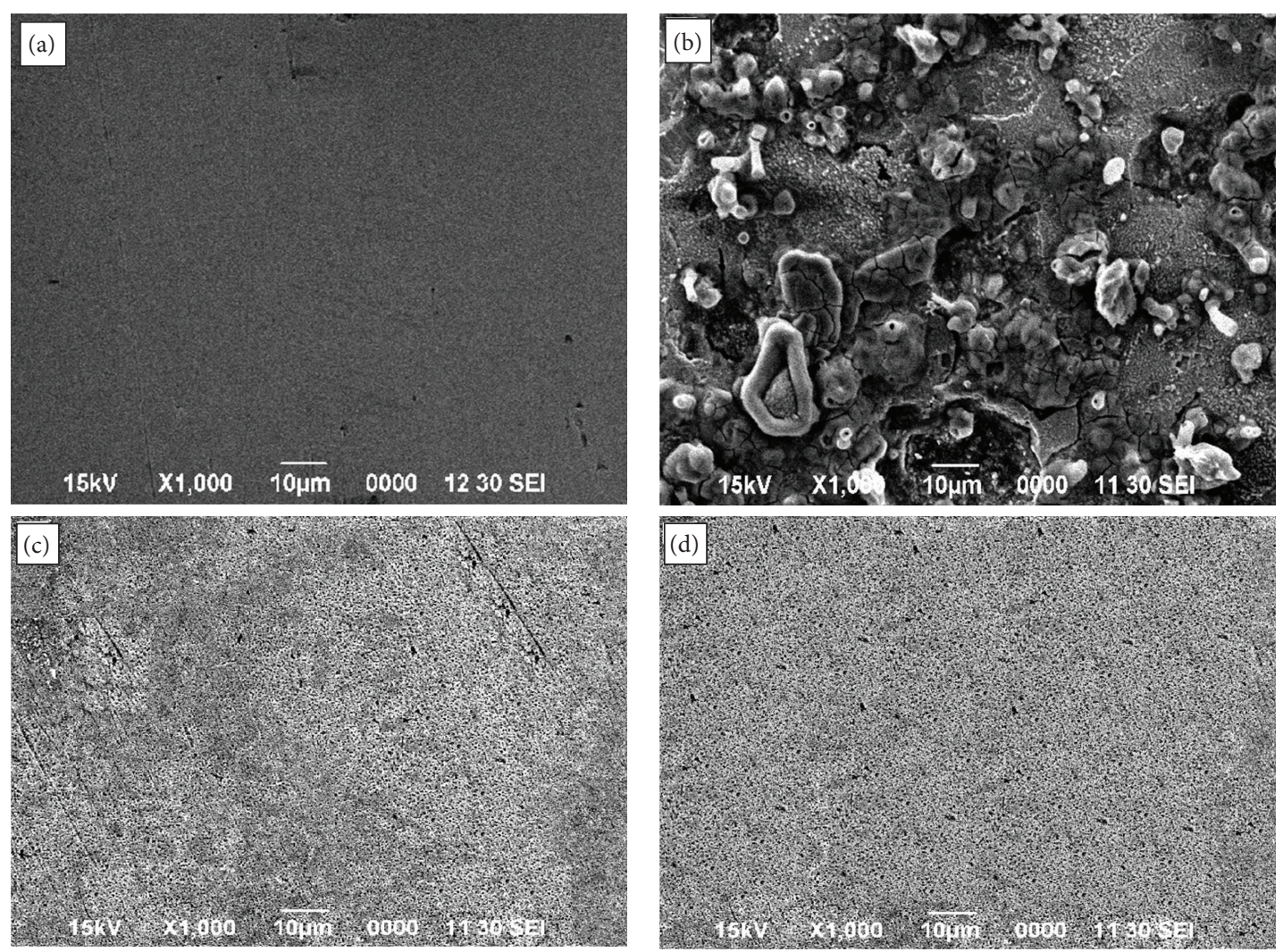

FIGURE 5: SEM photographs for mild steel (a) before immersion, (b) after immersion in $1 \mathrm{M} \mathrm{HCl,} \mathrm{(c)} \mathrm{after} \mathrm{immersion} \mathrm{in} 1 \mathrm{M}$ HCl with $2.23 \mathrm{mM} \mathrm{BBH},(\mathrm{d})$ after immersion in $1 \mathrm{M} \mathrm{HCl}$ with $2.00 \mathrm{mM}$ PABH.

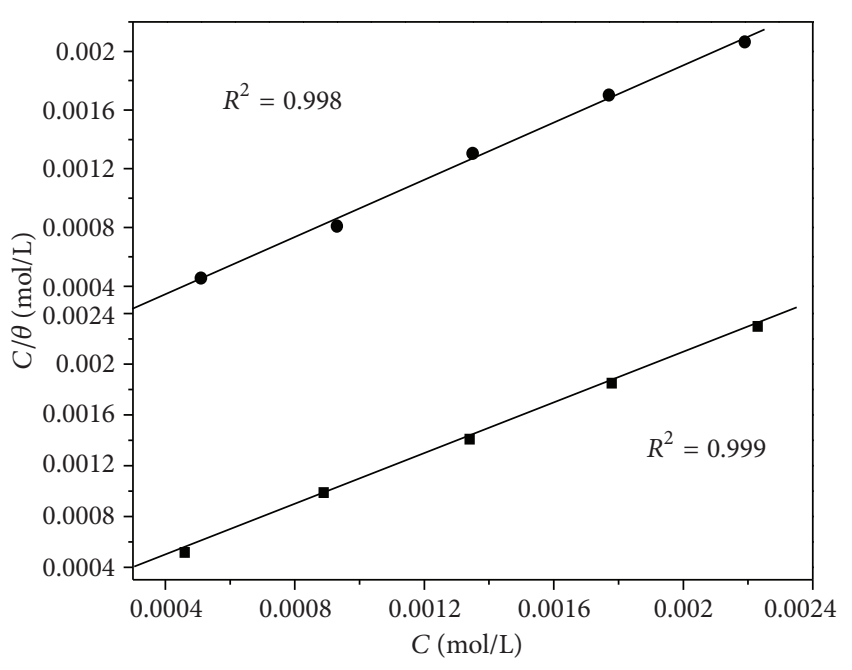

- $\mathrm{BBH}$

FIGURE 6: Langmuir adsorption isotherm plots for mild steel in (a) $1 \mathrm{M} \mathrm{HCl}$ containing $\mathrm{BBH}$ and (b) $1 \mathrm{M} \mathrm{HCl}$ containing $\mathrm{PABH}$.

charge sharing or charge transfer from organic molecules to the metal surface to form a coordinate type of bond (chemisorption) $[27,28]$. The presence of various electrons donating groups in the inhibitor molecules and delocalized aromatic ring may also provide electrostatic adsorption.
The free energy of activation for the corrosion process was $11.23 \mathrm{~kJ} / \mathrm{mole}$ which was raised to $29.26 \mathrm{~kJ} / \mathrm{mole}$ by $2.23 \mathrm{mM}$ of $\mathrm{BBH}$ and to $28.35 \mathrm{~kJ} / \mathrm{mole}$ by $2.00 \mathrm{mM}$ of $\mathrm{PABH}$. This increase in the free energy of activation for corrosion suggests that corrosion reaction is hindered. The adsorption of these molecules led to the formation of a physical barrier which reduced the metal reactivity in the electrochemical reactions of corrosion.

3.5. Mechanism of Inhibition. In chloride solutions [29], the dissolution of iron takes place as

$$
\begin{gathered}
\mathrm{Fe} \longrightarrow \mathrm{FeOH}_{\mathrm{ads}}+\mathrm{e}^{-} \\
\mathrm{FeOH}_{\mathrm{ads}} \longrightarrow \mathrm{FeOH}^{+}+\mathrm{e} \\
\mathrm{FeOH}^{+} \rightleftharpoons \mathrm{Fe}^{2+}+\mathrm{OH}^{-}
\end{gathered}
$$$$
\mathrm{Fe}^{2+}+m \mathrm{H}_{2} \mathrm{O}+n \mathrm{Cl}^{-} \longrightarrow\left[\mathrm{Fe}(\mathrm{OH})_{m}(\mathrm{Cl})_{n}^{2-n-m}\right]+m \mathrm{H}^{+}
$$

The overall reaction is

$$
\mathrm{Fe}^{2+}+m \mathrm{H}_{2} \mathrm{O}+n X \rightleftharpoons \mathrm{FeX}+n \mathrm{H}^{+}+2 \mathrm{e}
$$

The organic inhibitor molecules ( $\mathrm{BBH}$ and $\mathrm{PABH})$ may exist either as protonated using lone pair of electrons from $-\mathrm{NH}$ 
group or as a neutral molecule. This molecule can interact with $\left[\mathrm{Fe}(\mathrm{OH})_{m}(\mathrm{Cl})_{n}^{2-n-m}\right]$ intermediate to form a surface complex containing inhibitor.

In hydrochloric acid solutions without inhibitor, chloride ions may also adsorb on the electrode to form chlorocomplex [30] as suggested

$$
\begin{gathered}
\mathrm{Fe}+\mathrm{Cl}^{-} \rightleftharpoons \mathrm{FeCl}_{\mathrm{ad}}^{-} \\
\left(\mathrm{FeCl}^{-}\right)_{\mathrm{ads}} \longleftrightarrow\left(\mathrm{FeCl}_{\mathrm{ads}}\right)^{+}+\mathrm{e}^{-} \\
\left(\mathrm{FeCl}^{+}\right)_{\mathrm{ads}} \longrightarrow \mathrm{Fe}^{2+}+\mathrm{Cl}^{-}
\end{gathered}
$$

In hydrochloric acid solutions with inhibitors,

$$
\begin{gathered}
(\mathrm{FeCl})_{\mathrm{ads}}+\mathrm{Inh} \rightleftharpoons\left(\mathrm{FeCl}^{-} \mathrm{Inh}\right)_{\mathrm{ads}} \\
\left(\mathrm{FeCl}^{-} \mathrm{Inh}\right)_{\mathrm{ads}} \longrightarrow(\mathrm{FeInh})_{\mathrm{ads}}+\mathrm{Cl}^{-}
\end{gathered}
$$

\section{Conclusions}

The results showed that, $\mathrm{BBH}$ and $\mathrm{PABH}$ compounds offer corrosion inhibition for mild steel in $1 \mathrm{M} \mathrm{HCl}$ solution. These compounds spontaneously chemisorbed obeying Langmuir isotherm. The free energy of activation values for corrosion process was suggested that the compounds participated in the corrosion process. The adsorbed chloro-inhibitor complex has offered better barrier protection to steel and thereby reduced corrosion. The positively charged complex was prevented; the formation of protons and retarded hydrogen evolution reaction. Surface morphology observations revealed the formation of a protective film.

\section{Acknowledgment}

The authors thank to University Grants Commission, (UGC), New Delhi for providing the research fund to carry out this research work.

\section{References}

[1] A. Raman, P. Labine, and M. A. Quraishi, Reviews on Corrosion Inhibitor Science and Technology, Springer, Berlin, Germany, 2004.

[2] M. Lebrini, M. Lagrenée, H. Vezin, M. Traisnel, and F. Bentiss, "Experimental and theoretical study for corrosion inhibition of mild steel in normal hydrochloric acid solution by some new macrocyclic polyether compounds," Corrosion Science, vol. 49, no. 5, pp. 2254-2269, 2007.

[3] K. C. Emregül, R. Kurtaran, and O. Atakol, "An investigation of chloride-substituted Schiff bases as corrosion inhibitors for steel," Corrosion Science, vol. 45, no. 12, pp. 2803-2817, 2003.

[4] S. A. Ali, M. T. Saeed, and S. U. Rahman, "The isoxazolidines: a new class of corrosion inhibitors of mild steel in acidic medium," Corrosion Science, vol. 45, no. 2, pp. 253-266, 2003.

[5] J. O. M. Bockris and A. K. N. Reddy, Modern Electrochemistry, Plenum Publishing Corporation, New York, NY, USA, 1976.

[6] M. A. Quraishi, M. Ajmal, and S. Shere, "Investigation on some aromatic Schiff bases as acid corrosion inhibitors for mild steel," in Proceedings of the 8th European Symposium on Corrosion
Inhibitors (8 SEIC), pp. 291-298, Annali dell'Universita di Ferrara, 1995.

[7] R. Solmaz, E. Altunba, and G. Karda, "Adsorption and corrosion inhibition effect of 2-((5-mercapto-1,3,4- thiadiazol-2ylimino)methyl)phenol Schiff base on mild steel," Materials Chemistry and Physics, vol. 125, no. 3, pp. 796-801, 2011.

[8] A. B. da Silva, E. D’Elia, and J. A. da Cunha Ponciano Gomes, "Carbon steel corrosion inhibition in hydrochloric acid solution using a reduced Schiff base of ethylenediamine," Corrosion Science, vol. 52, no. 3, pp. 788-793, 2010.

[9] A. M. Abdel-Gaber, M. S. Masoud, E. A. Khalil, and E. E. Shehata, "Electrochemical study on the effect of Schiff base and its cobalt complex on the acid corrosion of steel," Corrosion Science, vol. 51, no. 12, pp. 3021-3024, 2009.

[10] E. Bayol, T. Gürten, A. A. Gürten, and M. Erbil, "Interactions of some Schiff base compounds with mild steel surface in hydrochloric acid solution," Materials Chemistry and Physics, vol. 112, no. 2, pp. 624-630, 2008.

[11] I. Ahamad and M. A. Quraishi, "Mebendazole: new and efficient corrosion inhibitor for mild steel in acid medium," Corrosion Science, vol. 52, no. 2, pp. 651-656, 2010.

[12] I. Ahamad, R. Prasad, and M. A. Quraishi, "Thermodynamic, electrochemical and quantum chemical investigation of some Schiff bases as corrosion inhibitors for mild steel in hydrochloric acid solutions," Corrosion Science, vol. 52, no. 3, pp. 933-942, 2010.

[13] E. A. Noor and A. H. Al-Moubaraki, "Thermodynamic study of metal corrosion and inhibitor adsorption processes in mild steel/1-methyl-4[4' (-X)-styryl pyridinium iodides/hydrochloric acid systems," Materials Chemistry and Physics, vol. 110, no. 1, pp. 145-154, 2008.

[14] S. S. Abdel-Rehim, A. M. Magdy, and K. F. Khaled, "4-aminoantipyrine as an inhibitor of mild steel corrosion in $\mathrm{HCl}$ solution," Journal of Applied Electrochemistry, vol. 29, no. 5, pp. 593-599, 1999.

[15] S. S. Abdel-Rehim, A. M. Magdy, and K. F. Khaled, "Corrosion inhibition and adsorption behaviour of 4-aminoantipyrine on carbon steel in H2SO4," Corrosion Prevention and Control, vol. 46, p. 157, 1999.

[16] K. F. Khaled, S. S. Abdel-Rehim, and N. Hackerman, Annali dell'Universita di Ferrara, vol. 2, p. 713, 2000.

[17] S. Zhang, Z. Tao, W. Li, and B. Hou, "The effect of some triazole derivatives as inhibitors for the corrosion of mild steel in $1 \mathrm{M}$ hydrochloric acid," Applied Surface Science, vol. 255, no. 15, pp. 6757-6763, 2009.

[18] Z. Tao, S. Zhang, W. Li, and B. Hou, "Corrosion inhibition of mild steel in acidic solution by some oxo-triazole derivatives," Corrosion Science, vol. 51, no. 11, pp. 2588-2595, 2009.

[19] R. Solmaz, "Investigation of the inhibition effect of 5-((E)-4phenylbuta-1,3-dienylideneamino)-1,3,4-thiadiazole-2-thiol Schiff base on mild steel corrosion in hydrochloric acid," Corrosion Science, vol. 52, no. 10, pp. 3321-3330, 2010.

[20] S. M. A. Hosseini, M. Salari, E. Jamalizadeh, S. Khezripoor, and M. Seifi, "Inhibition of mild steel corrosion in sulfuric acid by some newly synthesized organic compounds," Materials Chemistry and Physics, vol. 119, no. 1-2, pp. 100-105, 2010.

[21] G. Schmitt, "Application of inhibitors for acid media," British Corrosion Journal, vol. 19, pp. 165-176, 1984.

[22] A. S. Fouda, M. Abdallah, and Z. El-Badrawy, African Journal of Pure and Applied Chemistry, vol. 5, no. 8, pp. 224-236, 2011. 
[23] K. Jüttner, "Electrochemical impedance spectroscopy (EIS) of corrosion processes on inhomogeneous surfaces," Electrochimica Acta, vol. 35, no. 10, pp. 1501-1508, 1990.

[24] T. Pajkossy, "Impedance of rough capacitive electrodes," Journal of Electroanalytical Chemistry, vol. 364, no. 1-2, pp. 111-125, 1994.

[25] M. Lebrini, F. Bentiss, H. Vezin, and M. Lagrenée, "The inhibition of mild steel corrosion in acidic solutions by 2,5 bis(4-pyridyl)-1,3,4-thiadiazole: structure-activity correlation," Corrosion Science, vol. 48, no. 5, pp. 1279-1291, 2006.

[26] F. B. Growcock and R. J. Jasinski, "Time-resolved impedance spectroscopy of mild steel in concentrated hydrochloric acid," Journal of the Electrochemical Society, vol. 136, no. 8, pp. 2310-2314, 1989.

[27] Z. Szklarska-Smialowska and J. Mankowski, "Crevice corrosion of stainless steels in sodium chloride solution," Corrosion Science, vol. 18, no. 11, pp. 953-960, 1978.

[28] A. Yurt, S. Ultas, and H. Dal, "Electrochemical and theoretical investigation on the corrosion of aluminium in acidic solution containing some Schiff bases," Applied Surface Science, vol. 253, no. 2, pp. 919-925, 2006.

[29] M. Jayalakshmi and V. S. Muralidharan, "Polymer-based phosphonic acid inhibitor for low chloride media," Indian Journal of Chemical Technology, vol. 5, no. 2, pp. 16-28, 1998.

[30] R. Solmaz, G. Kardas, M. Çulha, B. Yazıcı, and M. Erbil, "Investigation of adsorption and inhibitive effect of 2-mercaptothiazoline on corrosion of mild steel in hydrochloric acid media," Electrochemica Acta, vol. 53, no. 20, pp. 5941-5952, 2008. 

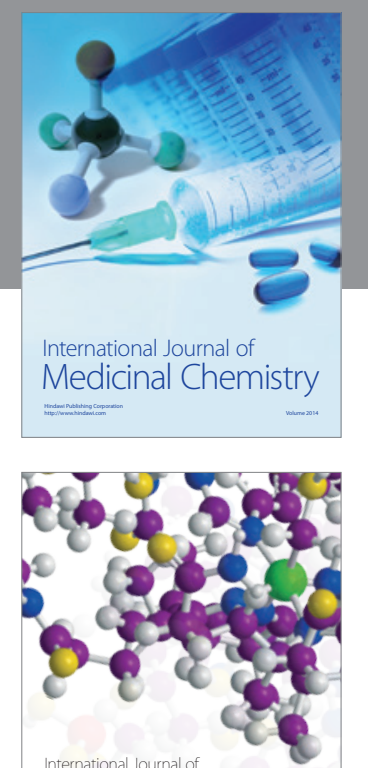

\section{Carbohydrate} Chemistry

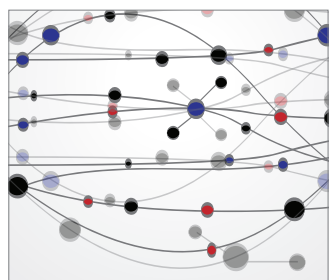

The Scientific World Journal
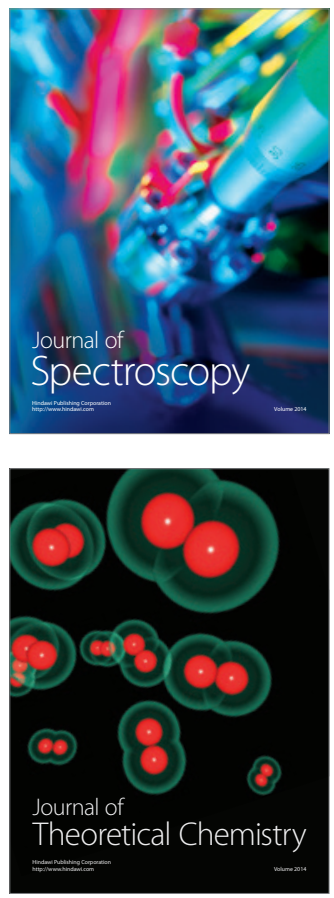
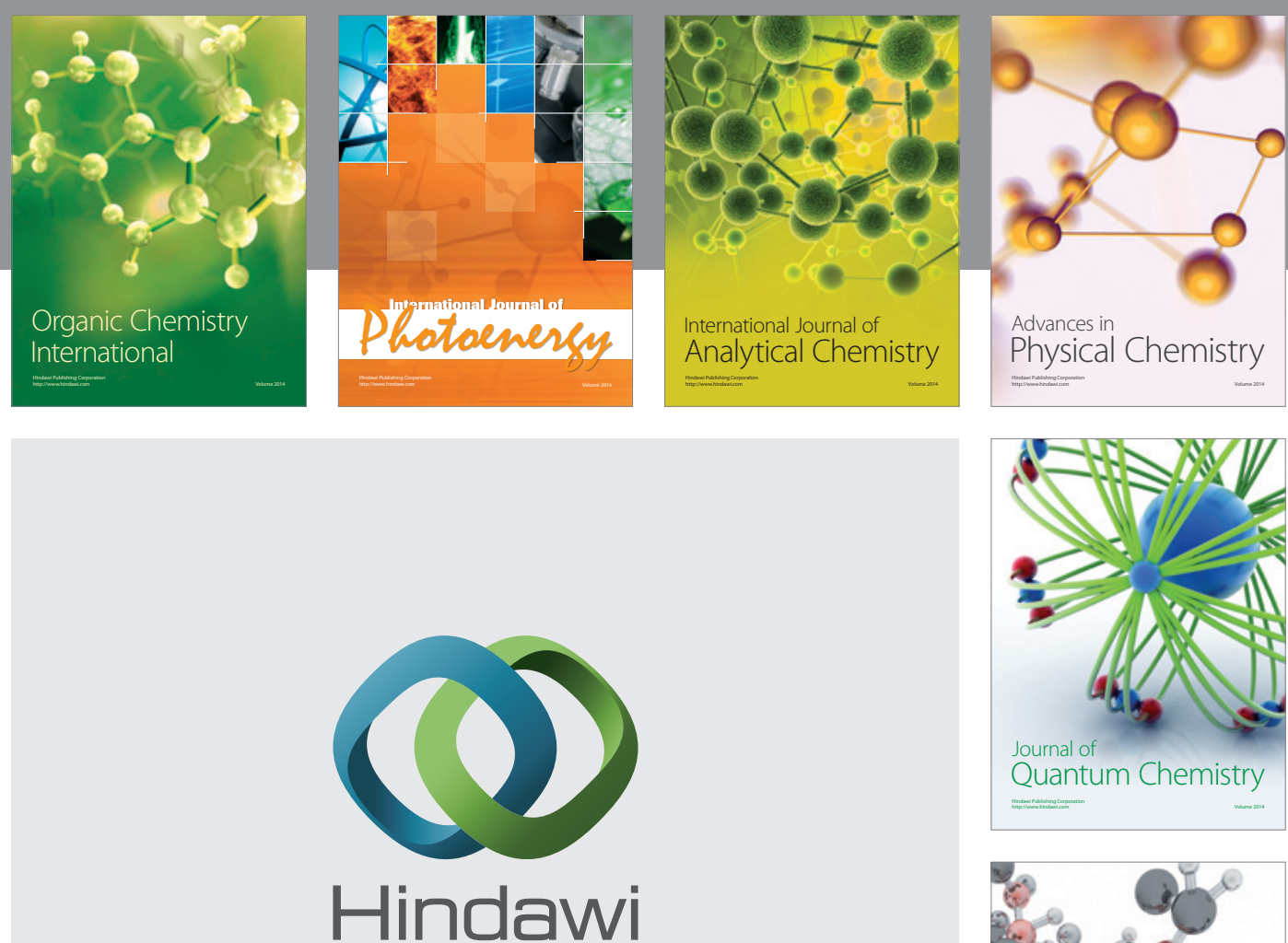

Submit your manuscripts at

http://www.hindawi.com

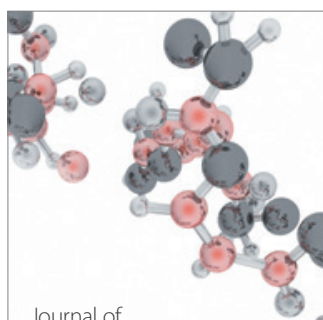

Analytical Methods

in Chemistry

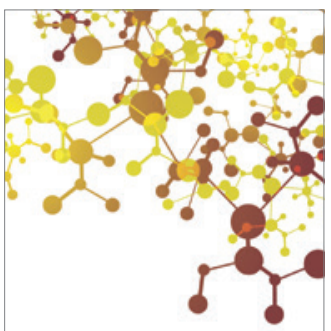

Journal of

Applied Chemistry

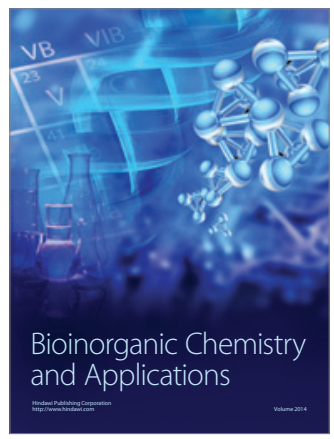

Inorganic Chemistry
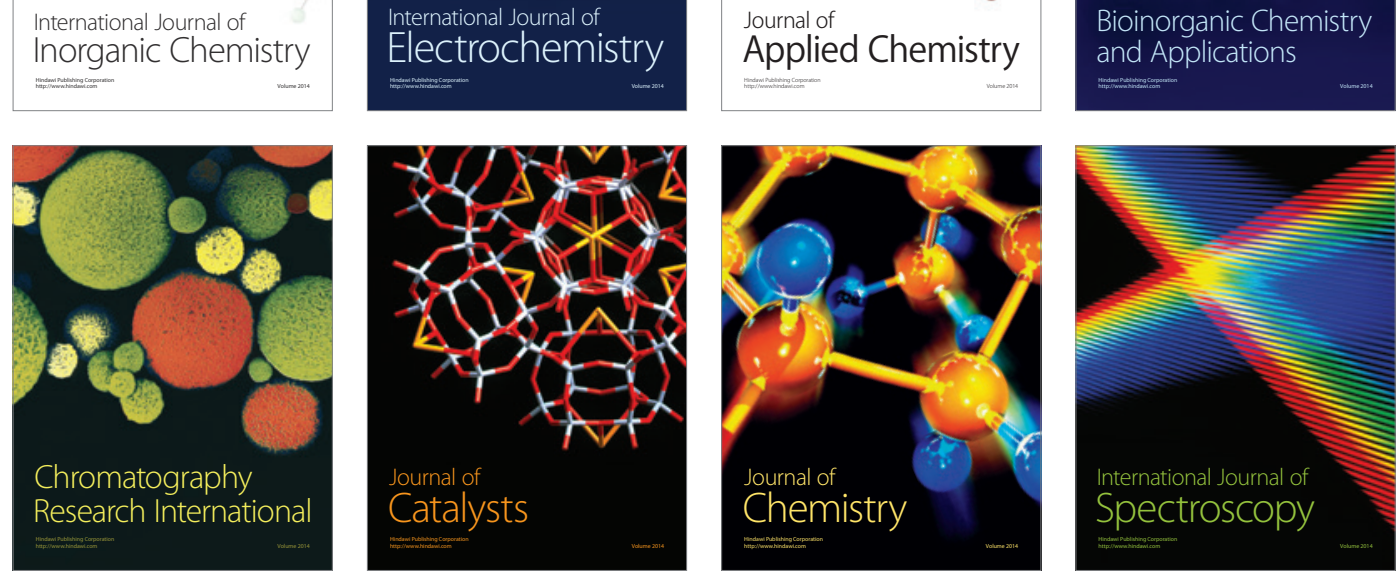